\title{
Distribution of Clinically Relevant Erythrocyte Antigens among Blood Donors of the Republic of Srpska
}

\section{ABSTRACT}

Introduction: Identifying voluntary blood donors with rare phenotype characteristics is the basic precondition for creating a registry of blood donors with rare blood groups.

\begin{abstract}
Aims of the study: Determining the presence of phenotypes in the clinically most relevant blood group systems in regular blood donors at the Institute for Transfusion Medicine of the Republic of Srpska, with the goal to create a national registry of blood donors with rare blood groups.
\end{abstract}

Patients and Methods: Determination of antigens in the Rh system was performed by the automatic microplate method, as well as by gel method. Determination of antigens in other blood group systems Kell, Kidd, Duffy, MNS, Lewis and Lutheran was performed by the gel method and test tube method. Altogether 384 blood donors were screened between 2012 and 2013.

Results: The analysis of Rh phenotypes showed that most of the examinees had the Rh phenotype CcDee ,29.7\% and $26.0 \%$ the ccddee, and the least of them had the Rh phenotype ccddEe 0.8\%, Ccddee 1.6\% and ccDee 2.3\%. The antigen Cw was proved to be in 13 donors (3.4\%), while the antigen P1 was detected in 291 donors (75.8\%). In analyzing the Lewis antigen system, most of the blood donors were found to have the phenotype Le (a-b+), 74.0\%. By analyzing the Lutheran antigen system, the phenotype $L u(a-b+)$ was detected in most of the donors typed for Lutherean antigens, that is, in $93.0 \%$ of them. One individual was found to have the phenotype Lu (a+b-) (0.3\%), and two donors the phenotype Lu (a-b-) (0.5\%). The analysis of the Kell antigen system showed most of the donors were of the phenotype kk, $93.2 \%$, one individual was found to have the phenotype $\mathrm{KK}(0.3 \%)$ and 25 donors the phenotype $\mathrm{Kk}$ (6.5\%). In analyzing the Kidd antigen system, most of the donors were found to have the phenotype Jk(a+b+), 46.6\% and $29.4 \%$ the Jk(a-b+), whereas $24.0 \%$ had the phenotype $\mathrm{Jk}(\mathrm{a}+\mathrm{b}-)$. According to the study of $\mathrm{MN}$ antigen in the MNS system, most of the donors were typed as MN, $50.0 \%$ and $33.9 \%$ as MM, while the phenotype NN was detected in $16.1 \%$ donors. Analyzing the $S$ and s antigens in the MNS system, the phenotypes Ss were found in most of the donors, $49.0 \%$ and ss in $43.2 \%$, whereas the phenotype SS was detected in $7.8 \%$ donors. The analysis of the Duffy antigen system showed most of the donors were of the phenotype Fy $(a+b+)$, $46.6 \%$ and $34.6 \%$ of the Fy(a-b+), while the phenotype Fy(a+b-) was observed in $18.8 \%$ donors.

Conclusion: Data on the distribution of clinically relevant erythrocyte antigens among regular blood donors in the Republic of Srpska is in accordance with the data set out in the literature for the caucasian.

Key Words: blood groups, erythrocyte antigens, distribution of clinically relevant erythrocyte antigens

\section{Gordana Guzijan1, Janja Bojanić2 , Dragica Jojić ${ }^{3}$, Biljana Jukić1, Sandra Mitrović1, Veselka Ćejić1}

${ }^{1}$ Institute for Transfusion Medicine of the Republic of Srpska, Banja Luka, BiH

${ }^{2}$ The Public Health Institute, the Republic of Srpska, Banja Luka, BiH ${ }^{3}$ The Paediatric Clinic, University Hospital Clinical Centre Banja Luka

\section{Contact address:}

Gordana Guzijan

Jovana Jančića 3

7800 o Banja Luka, BiH

E-mail: gordanaguzijan@yahoo.com Telephone: +38765829649 


\section{Introduction}

Blood groups are every variation or polymorphism in blood. According to the general definition, blood groups are inherited biological characteristics that, in healthy people, do not change throughout life. According to another definition, blood groups are antigens on the surface of red blood cells, which represent inherited characteristics of every individual and may be proved by specific antibodies, and they express refined structural difference in the erythrocyte cell membrane. ${ }^{1}$

In practice, the term blood group refers to antigens. Immunohematology is a branch that studies erythrocyte antigenantibody reactions.

Erythrocyte antigen can be divided according to: a) the clinical significance (they may cause hemolytic disease of the newborn or hemolytic transfusion reaction); b) the way of provoking immune response in the organism (exposure to similar antigens in the environment, when the so called natural antibodies are produced or immune response is stimulated by transfusion and pregnancy, respectively; when immune antibodies are produced); c) similarities in the biochemical structure. ${ }^{1-5}$

All the proved blood group antigens have been divided into: systems (at this moment we know about 35 of them), collections (there are 7 of them), and series (there are 2). ${ }^{3}$

Blood group antigens are classified into systems or collections, as they are defined immunologically, genetically and biochemically. In practice, first an anti-erythrocyte antibody is detected in the serum of a multigravida or politransfused patient. When its unique specificity is verified, the antibody is used for conducting researches of biochemical features and structure of antigens against which it was produced. Inheritance of the antigen and its genetic frequency are studied due to potential connection with the other, already detected antigens. Every antigen that belongs to any blood group system is presented by a six-digit number. The first three numbers mark the system (oo1-035), collection (205-213) or series (low-frequency antigens 700, and high-frequency antigens 901), whereas the other three numbers refer to the specificity of a certain antigen. For example, the Lutheran system is numbered 005, and the antigen $\mathrm{Lu}^{\mathrm{a}}$, as the first antigen of this system, has the number 001, i.e. 005001.

The clinically relevant erythrocyte antigens are, by definition, those that may cause erythrocyte hemolysis in vivo, when symptoms and signs of direct, i.e. delayed hemolytic transfusion reaction or clinical picture of the hemolytic disease of the newborn occur. The antigen systems Rh, Kell, Kidd, Duffy, MNS, etc. are considered to be clinically relevant erythrocyte antigens. ${ }^{4}$ Distribution of erythrocyte antigens was tested in various races and populations. The results of those tests indicate that there are differences in the distribution of some erythrocyte antigens among different races, as well as within certain nations of the same race.

\section{Aim of the study}

To determine the distribution of clinically relevant erythrocyte antigens $\mathrm{C}, \mathrm{c}, \mathrm{E}, \mathrm{e}, \mathrm{C}^{\mathrm{w}}, \mathrm{K}, \mathrm{k}, \mathrm{Kp}^{\mathrm{a}}, \mathrm{Kp}^{\mathrm{b}}, \mathrm{M}, \mathrm{N}, \mathrm{S}, \mathrm{s}, \mathrm{Fy}^{\mathrm{a}}$, $\mathrm{Fy}^{\mathrm{b}}, \mathrm{Jk}^{\mathrm{a}}, \mathrm{Jk}^{\mathrm{b}}, \mathrm{Lu}^{\mathrm{a}}, \mathrm{Lu}^{\mathrm{b}}$, as well as the antigens $\mathrm{P}_{1}, \mathrm{Le}^{\mathrm{a}}$ and $\mathrm{Le}^{\mathrm{b}}$ in the population of regular blood donors on the territory of Banja Luka and the Republic of Srpska.

To compare the found frequencies of the distribution of erythrocyte antigens with the frequencies in other tested white populations.

\section{Patients and Methods}

In this prospective study a total of 384 examinees were studied during 2012 and 2013, the population of regular blood donors at the Institute for Transfusion Medicine Banja Luka, males and females, the age of 18 through 55, with the blood groups $\mathrm{A}$ and $\mathrm{O}, \mathrm{RhD}$-positive and $\mathrm{RhD}$ negative. Blood donors of the blood group A b were tested, as that was the most common blood group in this climate, as well as the blood group $\mathrm{O}$, as those were regarded as „universal” erythrocyte donors (Table 1.).

The examinees belonged to the category of regular blood donors, who gave their blood at least twice before the screening, and their results upon the testing of presence of the markers for transfusion transmissible diseases had been

Table 1. Distribution of blood donors by blood transfusion centers at the Institute for Transfusion Medicine Banja Luka in 2013

\begin{tabular}{lcccccccccccc}
\hline 2013 & BL & DO & PR & GR & BN & ZV & TR & KS & FO & NE & TOTAL \\
\hline $\begin{array}{l}\text { Number of taken doses } \\
\text { of blood }\end{array}$ & 10114 & 4830 & 2327 & 2583 & 4078 & 2074 & 1690 & 1524 & 1332 & 50 & 30602 \\
\hline $\begin{array}{l}\text { Number of voluntary } \\
\text { blood donors }\end{array}$ & 5710 & 2541 & 1820 & 1824 & 3460 & 1014 & 1712 & 642 & 373 & 50 & 19146 \\
\hline \begin{tabular}{l} 
Number of women \\
\hline
\end{tabular} & $157 \%$ & $53 \%$ & $78 \%$ & $71 \%$ & $73 \%$ & $40 \%$ & $99 \%$ & $42 \%$ & $28 \%$ & $100 \%$ & $64,04 \%$ \\
\hline
\end{tabular}


negative. In 2013, there were 5710 blood donors in Banja Luka, covering $7 \%$ of the total number of blood donors on this territory.

The frequency of the clinically most relevant erythrocyte antigens was studied in this sample, including implicitly $\mathrm{Rh}$ phenotypes, C, c, E, e, also including the $\mathrm{C}^{\mathrm{w}}$ antigen, $\mathrm{K}, \mathrm{k}, \mathrm{Kp}^{\mathrm{a}}$ and $\mathrm{Kp}^{\mathrm{b}}$ antigens in the Kell system, M, N, S, and $\mathrm{s}$ antigens in the MNS system, $\mathrm{Fy}^{\mathrm{a}}$ and $\mathrm{Fy}^{\mathrm{b}}$ antigens in the Duffy system, $\mathrm{Jk}^{\mathrm{a}}$ and $\mathrm{Jk}^{\mathrm{b}}$ antigens within the Kidd system, $\mathrm{Lu}^{\mathrm{a}}$ and $\mathrm{Lu}^{\mathrm{b}}$ of the Lutheran system, as well as $\mathrm{Le}^{\mathrm{a}}$ and Le ${ }^{\mathrm{b}}$ antigens of the Lewis system and $\mathrm{P}_{1}$ antigen. Blood samples were taken in the appropriate vacutainer with anticoagulant EDTA, as prescribed on the Techno device instructions.

To determine the blood groups and red blood cell/erythrocyte antigen typing, the following methods were applied: a) test tube method or agglutination in an aqueous environment, ${ }^{6-8} \mathrm{~b}$ ) gel method, ${ }^{9} \mathrm{c}$ ) microplate method. ${ }^{10,11}$

In this study. the process implied automatic testing of blood groups $\mathrm{ABO}$ and $\mathrm{RhD}$ antigens, as well as Rh phenotypes from donors' samples in the Techno device (DiaMed) ${ }^{12}$, by microplate method, and gel method, test serums DiaMed. In this way we had electronic entry in the Lira reader and any error in copying was avoided. As for the determining of other blood group systems, the first time it was performed by gel method (DiaMed), and the second time by test tube method, by using the serum Biognost Zagreb, Novaclone Canada, Sanguin Holand, Immucor USA, Diagast France.

The primarily obtained data was analyzed by descriptive statistic methods. As descriptive statistic method the following was used: central tendency measures (arithmetic environment), variability measures (standard deviation) and structure indicators expressed in percentages.

\section{Results}

In the tested sample the highest percentage of blood donors were those of group $\mathrm{A}, \mathrm{RhD}+35.9 \%$ (Figure 1.).

Figure 1. Distribution of blood groups in relation to the $A B O$ system and $R h D$ antigen

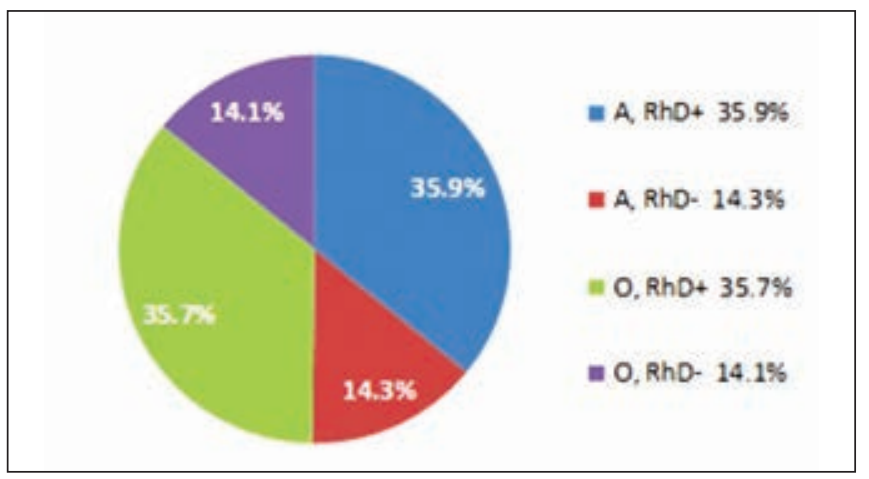

Analysis of Rh phenotypes in the tested sample of blood donors showed that most of the examinees were found to have the Rh phenotype CcDee ,29.7\% and $26.0 \%$ the ccddee, and that the least of them had the Rh phenotype ccddEe 0.8\%, Ccddee 1.6\% and ccDee 2.3\%. (Table 2.).

Table 2. Frequency of Rh phenotypes in the sample of blood donors in the Republic of Srpska

\begin{tabular}{cc}
\hline Rh fenotip & $n(\%)$ \\
\hline CcDEe & $45(11.7)$ \\
\hline ccDEe & $36(9.4)$ \\
\hline CcDee & $114(29.7)$ \\
\hline ccDEE & $8(2.1)$ \\
\hline ccddee & $100(26.0)$ \\
\hline CCDee & $63(16.4)$ \\
\hline ccDee & $9(2.3)$ \\
\hline ccddEe & $3(0.8)$ \\
\hline Ccddee & $6(1.6)$ \\
\hline Total & $384(100.0)$ \\
\hline
\end{tabular}

In the tested sample of blood donors. the antigen $\mathbf{C}^{\mathbf{w}}$ was verified in 13 of them (3.4\%).

In the tested sample of blood donors the antigen $\mathbf{P}_{\mathbf{1}}$ was detected in 291 of them (75.8\%).

After analyzing the Lewis antigen system in the tested sample of blood donors, most of the blood donors were found to have the phenotype $\operatorname{Le}(a-b+), 74.0 \%$.

By analyzing the Lutheran antigen system in the tested sample of donors, the phenotype $\mathrm{Lu}(\mathrm{a}-\mathrm{b}+)$ was detected in most of the donors typed for Lutheran antigens, in 93.0\%. One individual was found to have the phenotype $\mathrm{Lu}(\mathrm{a}+\mathrm{b}-)$ (0.3\%), and two donors the phenotype Lu(a-b-) (0.5\%).

The analysis of the Kell antigen system in the tested sample of blood donors showed that most of the donors had the phenotype kk, $93.2 \%$ of them, one individual was found to have the phenotype KK (0.3\%) and 25 donors the phenotype $\mathrm{Kk}(6.5 \%)$.

In analyzing the $\mathbf{K p}$ antigen in the Kell system in the tested sample of blood donors, the phenotype $\mathrm{Kp}(\mathrm{a}-\mathrm{b}+)$ was detected in most of the examinees, in $97.9 \%$ of them, whereas the phenotype $\mathrm{Kp}(\mathrm{a}+\mathrm{b}+)$ was observed in 8 donors (2.1\%).

The analysis of the Kidd antigen system in the tested sample of blood donors showed that most of the had the phenotype $\mathrm{Jk}(\mathrm{a}+\mathrm{b}+), 46.6 \%$ and $29.4 \%$ the phenotype $\mathrm{Jk}(\mathrm{a}-\mathrm{b}+)$, whereas the phenotype $\mathrm{Jk}(\mathrm{a}+\mathrm{b}-)$ was observed in 24.0\% donors (Table 3.). 
Table 3. Distribution of the Kidd antigen system in the sample of blood donors in the Republic of Srpska

\begin{tabular}{cc}
\hline Antigen system Kidd & $n(\%)$ \\
\hline$J k(a+b+)$ & $179(46.6)$ \\
\hline$J k(a+b-)$ & $92(24.0)$ \\
\hline$J k(a-b+)$ & $113(29.4)$ \\
\hline$J k(a-b-)$ & $0(0.0)$ \\
\hline Total & $384(100.0)$ \\
\hline
\end{tabular}

By studying the $\mathbf{M N}$ antigen in the MNS system, in the tested sample of blood donors, most of the donors were typed as MN, 50.0\% and $33.9 \%$ as MM, while the phenotype $\mathrm{NN}$ was detected in $16.1 \%$ donors. (Table 4.).

Table 4. Distribution of the MNS antigen system in the sample of blood donors in the Republic of Srpska

\begin{tabular}{cc}
\hline $\begin{array}{c}\text { Antigen MN } \\
\text { system MNS }\end{array}$ & $\mathrm{n}(\%)$ \\
\hline MN & $192(50.0)$ \\
\hline MM & $130(33.9)$ \\
\hline NN & $62(16.1)$ \\
\hline Null fenotip & $0(0.0)$ \\
\hline Total & $384(100.0)$ \\
\hline
\end{tabular}

Analyzing the $\mathbf{S}$ and $\mathbf{S}$ antigens in the MNS system, in the tested sample of blood donors, the phenotypes Ss were found in most of the donors, $49.0 \%$ and ss in $43.2 \%$, whereas the phenotype SS was detected in $7.8 \%$ donors.

As for the Duffy antigen system, most of the donors were found to have the phenotype $\mathrm{Fy}(\mathrm{a}+\mathrm{b}+), 46.6 \%$ and $34.6 \%$ the Fy(a-b+), while the phenotype Fy(a+b-) was observed in $18.8 \%$ donors.

\section{Discussion}

By analyzing the data of the observed sample, it was determined that $50 \%$ examinees belonged to the blood group $\mathrm{A}$, and nearly $50 \%$ to the blood group O. The situation was similar in regard to the $\mathrm{ABO}$ and $\mathrm{RhD}$ : about equal percentage of donors belonged to the blood group A, $\mathrm{RhD}+($ poz) and $\mathrm{O}, \mathrm{RhD}+(\mathrm{poz})-$ about $36 \%$. As donors who gave blood at least twice were selected for the study, and they were supposed to belong to the blood groups A and O, no wonder there was such a distribution. The most common blood group in populations of the former Yugoslavia was A ${ }^{1}$ and people with blood group $\mathrm{O}$ were said to be universal erythrocyte donors. ${ }^{1}$ The frequency of blood groups $\mathrm{ABO}$ in white donors was as follows: $\mathrm{O}-44 \%, \mathrm{~A}-43 \%, \mathrm{~B}-9 \%, \mathrm{AB}-$ $4 \%$. As for black donors, the frequency was the following:
$\mathrm{O}-49 \%, \mathrm{~A}-27 \%, \mathrm{~B}-20 \%, \mathrm{AB}-4 \%$, whereas the blood group $\mathrm{O}$ frequency in the yellow race was $43 \%, \mathrm{~A}-27 \%, \mathrm{~B}-25 \%$, and $\mathrm{AB}-5 \% .{ }^{13,14}$

When it comes to the distribution of antigens of the $\mathrm{Rh}$ phenotype, in the examined donor population, the most common phenotype was CcDee, with the frequency of about 30\%. The second most frequent was the phenotype CCDee with about $16 \%$, followed by CcDEe with about $12 \%$, ccDEe with about $9 \%$, ccDee and ccDEE with about $2 \%$ frequency. In RhD-negative people, the phenotype ccddee frequency was found to be about $26 \%$ in the tested sample, which was considerably more than the D antigen frequency in the white population. This may be due to the fact that this examination included the selected regular blood donors of blood groups A and O, RhD-pos. and RhD-neg, according to the need for examination of the distribution of erythrocyte antigens, and not according to the observance of $\mathrm{D}$ antigens in the white population, ranging from $12 \%$ to $18 \%{ }^{15^{-17}}$ Frequency of RhD-negative persons in the population of soldiers of the former Yugoslavia was 15,5\%, whereas $\mathrm{RhD}$-positive $84,5 \% .{ }^{1}$

In the sample of blood donors, it was determined that the $\mathrm{C}^{\mathrm{w}}$ antigen was in 13 of them (approx. $3 \%$ ). The $\mathrm{C}^{\mathrm{w}}$ and $\mathrm{C}^{\mathrm{x}}$ antigens were alleles of the high-frequency MAR antigen, and not, as it was originally believed, the alleles of $\mathrm{C}$ and $\mathrm{c}$ antigens. $\mathrm{C}^{\mathrm{w}}$ was an antigen with relatively low frequency in all populations. In the population of England the $\mathrm{C}^{\mathrm{w}}$ antigen had 2,6\% frequency, and similar data was found also for other white nations. ${ }^{15-17}$

In the sample of blood donors, 291 (75.8\%) of them were found to have the $\mathrm{P}_{1}$ antigen. The $\mathrm{P}_{1}$ antigen frequency of blood donors in the group of males was $76.4 \%$, whereas in the group of females it was $70.3 \%$. The $\mathrm{P}_{1}$ ( $\mathrm{P}_{1}$-positive) and $\mathrm{P}_{2}\left(\mathrm{P}_{1}\right.$-negative) phenotypes were present with the frequency of over $99 \%$ in the blood donor population. To show both phenotypes it was necessary to have the synthesis of $\mathrm{Pk}$ and $\mathrm{P}$ antigens, which differ from one another only in the expression of $\mathrm{P}_{1}$ antigen. Furthermore, three rare autosomal recessive phenotypes $\left(\mathrm{p}, \mathrm{P}_{1}{ }^{\mathrm{k}}, \mathrm{P}_{2}{ }^{\mathrm{k}}\right)$ were identified, as well as poor variants of the $P_{1}$ antigen..$^{6,18}$ The $\mathrm{P}_{1}$ phenotype frequency was in accordance with the presence of this phenotype in other white nations.

In analyzing the Lewis antigen system, most of the examined blood donors in the Republic of Srpska were found to have the phenotype $\operatorname{Le}(a-b+) 74.0 \%$, followed by phenotype Le $(a+b-)$, with about $16 \%$ of presence, and phenotype Le(a-b-) with the distribution of about $10 \%$. The Le $(a-b-)$ phenotype frequency was higher in people originated in Africa, as compared to other populations. ${ }^{6-8}$ Distribution of the Lewis antigens among the blood donors in the Republic of Srpska was in accordance with the data released for the white race. 
In analyzing the Lutheran antigen system, most of the examinees of the tested sample of blood donors in the Republic of Srpska were observed to have the phenotype $\mathrm{Lu}(\mathrm{a}-\mathrm{b}+) \mathrm{93.0 \%}$, one person was found to have the phenotype $\mathrm{Lu}(\mathrm{a}+\mathrm{b}-)(0.3 \%)$ and two donors the phenotype $\mathrm{Lu}(\mathrm{a}-\mathrm{b}-)$ (0.5\%). The $\mathrm{Lu}^{\mathrm{a}}$ (LU1) antigen frequency was about 8\% in Europeans and Africans, but it was rare in all other parts of the world. Its antithetical antigen $\mathrm{Lu}^{\mathrm{b}}$ (LU2) was present in all populations. ${ }^{6,18}$ The presence of $\mathrm{Lu}^{\mathrm{a}}$ and $\mathrm{Lu}^{\mathrm{b}}$ antigens was in accordance with the presence in other white populations.

The analysis of $\mathrm{K}$ and $\mathrm{k}$ antigens in the Kell system in the tested sample of blood donors in the Republic of Srpska showed that most of the examinees had the phenotype $\mathrm{kk} 93.2 \%$, one person was found to have the phenotype KK (0.3\%) and 25 donors the phenotype Kk (6.5\%). Distribution of Kand $k$ antigens in the examined population was in accordance with the published data. ${ }^{6,18}$

Analyzing the Kp antigen in the Kell system in the tested sample of blood donors, the phenotype $\mathrm{Kp}(\mathrm{a}-\mathrm{b}+)$ was detected in most of the examinees, in $97.9 \%$ of them, whereas the phenotype $\mathrm{Kp}(\mathrm{a}+\mathrm{b}+)$ was observed in 8 donors (2.1\%). According to the available data, such distribution was fully in correlation with the results of examinations performed on white donors in other countries. ${ }^{6,18}$

In analyzing the Kidd antigen system in the tested sample of blood donors, most of the donors were found to have the phenotype $\mathrm{Jk}(\mathrm{a}+\mathrm{b}+), 46.6 \%$ and $29.4 \%$ the phenotype $\mathrm{Jk}(\mathrm{a}-\mathrm{b}+)$, whereas the phenotype $\mathrm{Jk}(\mathrm{a}+\mathrm{b}-)$ was observed in $24.0 \%$ donors. The results were similar to the ones published in available literature. ${ }^{6,18}$

By studying the MN antigen in the MNS system, most of the donors were typed as $\mathrm{MN}, 50.0 \%$ and $33.9 \%$ as $\mathrm{MM}$, while the phenotype $\mathrm{NN}$ was detected in $16.1 \%$ donors.

Analyzing the $\mathrm{S}$ and s antigens in the MNS system, in the tested sample of blood donors, the phenotypes Ss were found in most of the donors, $49.0 \%$ and ss in $43.2 \%$, whereas the phenotype SS was detected in $7.8 \%$ donors. This was based on results and comparisons made with the usage of similar examinations of the white population in other countries. ${ }^{6,18}$

As for the Duffy antigen system, most of the donors were found to have the phenotype $\mathrm{Fy}(\mathrm{a}+\mathrm{b}+), 46.6 \%$ and $34.6 \%$ the Fy(a-b+), while the phenotype Fy(a+b-) was observed in $18.8 \%$ donors. Based on the presented data, it may be concluded that the results of this study are in correlation with the findings received for the phenotypes of the Duffy system in the previous examinations. ${ }^{6,18}$

Examining the distribution of erythrocyte antigens among blood donors is certainly a significant measure taken in setting up the Registry of Blood Donors with Rare Blood Groups. Naturally, it first starts with the clinically relevant and most present erythrocyte antigens in a given population. Nonetheless, the examination needs to be expanded on antigen frequency that in the examined populations are said to be rare.

Examinations performed in this study constitute a starting point for creating the Registry of blood donors with rare blood groups in the Republic of Srpska, as it refers to a show-sample of regular blood donors, and they will to a large degree instantly facilitate the provision of compatible blood to sensibilised patients.

\section{Conclusion}

Distribution of clinically relevant erythrocyte antigens of the Rh phenotype (C, c, D, E, e) and $\mathrm{C}^{\mathrm{w}}$ antigen within the Rh system, $\mathrm{K}, \mathrm{k}, \mathrm{Kp}^{\mathrm{a}}, \mathrm{Kp}^{\mathrm{b}}$ antigens within the Kell system, $\mathrm{M}, \mathrm{N}, \mathrm{S}$, s antigens within the MNS system, $\mathrm{Fy}^{\mathrm{a}}$, Fy ${ }^{\mathrm{b}}$ antigens within the Duffy system, $\mathrm{Jk}^{\mathrm{a}}$ and $\mathrm{Jk}^{\mathrm{b}}$ antigens within the Kidd system, $\mathrm{Lu}^{\mathrm{a}}$ and $\mathrm{Lu}^{\mathrm{b}}$ in the Lutheran system, and $\mathrm{P}_{1}$, $\mathrm{Le}^{\mathrm{a}}$ and $\mathrm{Le}^{\mathrm{b}}$ antigens in the Lewis system in the examined population of regular blood donors on the territory of Banja Luka was determined and was in accordance with the examined and published frequencies for the white population of different countries.

Examinations performed in this study represent a starting point for creating the Registry of blood donors with rare blood groups in the Republic of Srpska, as it refers to a show-sample of regular blood donors, and they will, to a large degree, instantly facilitate the provision of compatible blood to sensibilised patients.

\section{References}

1. Radović M. Biološki i klinički značaj krvnih grupa. U: Stefanović S. Hematologija. II, dopunjeno i prerađeno izdanje. BeogradZagreb: Medicinska knjiga, 1989; s.523-556.

2. Giblett E.R., u Williams, W.J. et al. Hematology, $3^{\text {rd }}$ edition McGraw Hill Book Comp., New York, 1491, 1986.

3. Daniels G. Human blood groups: introduction, terminology and function. In: Daniels G: Human Blood Groups. $2^{\text {nd }}$ ed. Oxford: Blackwell Science, 2002; pp.1-7.

4. Lizza C, Myers J, Gindy L. Blood groups. In: Petz LD: Clinical Practice of transfusion medicine, 3rd ed. New York(eds): Churchill Livingstone Inc,1996; pp. 71-153.

5. Calhoun L, Petz DL: Erythrocyte antigens and antibodies. In: Williams J. Hematology, 5th ed. New York: McGraw Hill Inc. 1995;1595-1610.

6. Jovanović Srzentić S., Veljković D. Imunobiološki i klinički značaj krvnih grupa. IntraNet Communication, Beograd, 2009.

7. Rodgers RP. Clinical Laboratory Methods for Detection of Antigen and Antibodyes. In: Stites DP, Terr AI, Parslow TG. Editors. Basic and Clinical Immunology. Connecticut: Appleton and Lange, 1994.p.151-95. 
8. Voak D. The status of new methods for detection of red cell agglutination.Transfusion 1999; 39:1037:40.

9. Knowles SM, Milkins EC, Chapman JF, Scoot M. The United Kingdom National External Quality Assessment Scheme (Blood Transfusion Laboratory Practice): trends in proficiency and practice between 1985 and 2000. Transfus Med 2002; 12:11-23.

10. Chung A, Birch P, Ilagan K. A microplate system for ABO and RhD blood grouping. Transfusion 1993; 33: 384-8.

11. Sevems ML, Schoeppener SL, Cozart MJ, Friedman LI, Schanfield MS. Automated determination of $\mathrm{ABO} / \mathrm{Rh}$ in microplates. Vox Sang 1984; 47:293-6.

12. British Committe for Standards in Haematology. Guidelines for compatibility procedures in blood transfusion laboratories. Transfus Med 2004;14:59-73.
13. Daniels G. ABO, Hh and Lewis system.In: Daniels G. Human Blood Groups. 2nd ed. Oxford: Blackwell Science, 2002. p.7-98.

14. Daniels G, Bromilow I. The ABO blood groups. In: Essential Guide to Blood Groups. Blackwell Publishing, 2007; p.20-32.

15. Klein HG, Anstee DJ, The Rh blood group system (and LW) In: Klein HG, Anstee DJ. Mollison's Blood Transfusion in Clinical Medicine.11th ed. Blackwell Publishing, 2007; p.163-208.

16. Daniels G. Rh blood group system. In: Daniels G. Human Blood Groups. 2nd ed. Oxford: Blackwell Science, 200; p.195-274.

17. Westhoff CM. Review: The Rh blood group D antigen. Dominant, diverse, and difficult. Immunohematology 2005; 21:155-63.

18. Daniels G. Other Blood groups. U: Roback JD, Combs MR, Grossman BJ,Hikkyer CD. Technical Manual, 16thed.Bethesda, Maryland, AABB, 2008; p.411-36.

\section{Distribucija klinički značajnih eritrocitnih antigena u populaciji davalaca krvi Republike Srpske}

\section{SAŽETAK}

Uvod: Identifikovanje dobrovoljnih davalaca krvi sa rijetkim fenotipskim karakteristikama je osnovni preduslov za formiranje registra davalaca krvi sa rijetkim krvnim grupama.

Cilj rada: Utvrđivanje procentualne zastupljenosti fenotipova klinički najznačajnijih krvnogrupnih sistema kod redovnih davalaca krvi u Zavodu za transfuzijsku medicine Republike Srpske, sa ciljem da se formira nacionalni registar davalaca rijetkih krvnih grupa.

Ispitanici i metode: Određivanje antigena Rh sistema je obavljeno automatskom metodom u mikropločama, kao i metodom u gelu. Određivanje antigena drugih krvnogrupnih sistema Kell, Kidd, Duffy, MNS, Lewis i Lutheran je rađeno metodom u gelu i metodom u epruvetama. Tokom 2012. i 2013.godine ispitana su 384 davaoca krvi.

Rezultati: Analizom Rh fenotipa najviše ispitanika je Rh fenotipa CcDee 29.7\% i ccddee 26.0\%, a najmanje Rh fenotipa ccddEe 0.8\%, Ccddee 1.6\% i ccDee 2.3\%. Antigen Cw je dokazan kod 13 davalaca (3.4\%), a antigen P1 kod 291 davaoca (75.8\%) . Analizom antigena sistema Lewis, najviše davalaca je sa fenotipom Le (a-b+) 74.0\%. Analizom antigena sistema Lutheran, najviše davalaca je sa fenotipom Lu (a-b+) 93.0\% . Kod jedne osobe je pronađen fenotip Lu (a+b-) (0.3\%), a kod dva davaoca fenotip Lu(a-b-) (0.5\%). Analizom antigena sistema Kell, najviše davalaca je sa fenotipom kk 93.2\%, kod jedne osobe je pronađen fenotip KK (0.3\%) i kod 25 davalaca fenotip Kk (6.5\%). Analizom antigena sistema Kidd, najviše davalaca je sa fenotipom Jk(a+b+) 46.6\% i sa Jk(a-b+) 29.4\%, a fenotip Jk(a+b-) ima 24.0\%. Ispitivanjem antigena MN sistema MNS, najviše je davalaca sa fenotipom MN $50.0 \%$ i sa MM 33.9\%, a fenotip NN je zastupljen kod 16.1\% davalaca.. Analizom antigena S i s sistema MNS, najviše davalaca je sa fenotipovima Ss $49.0 \%$ i ss $43.2 \%$, a kod 7.8\% davalaca je pronađen fenotip SS. Analizom antigena sistema Duffy, najviše davalaca je sa fenotipom Fy(a+b+) 46.6\% i sa Fy (a-b+) 34.6\%, a fenotip Fy(a+b-) je zastupljen kod 18.8\% davalaca.

Zaključak: Podaci o distribuciji klinički značajnih eritrocitnih antigena u populaciji redovnih davalaca krvi Republike Srpske su u skladu sa podacima iz literature za bijelu rasu.

Ključne riječi: krvne grupe, eritrocitni antigeni, distribucija klinički značajnih eritrocitnih antigena 